Article

\title{
Biocatalytic Oxidations of Substrates through Soluble Methane Monooxygenase from Methylosinus sporium 5
}

\author{
Yeo Reum Park ${ }^{1}$, Hee Seon Yoo ${ }^{1}$, Min Young Song ${ }^{1}$, Dong-Heon Lee ${ }^{1}$ and Seung Jae Lee ${ }^{1,2, *}$ \\ 1 Department of Chemistry and Institute for Molecular Biology and Genetics, Chonbuk National University, \\ Jeonju 54896, Korea; parkyr@jbnu.ac.kr (Y.R.P.); heeseon0202@jbnu.ac.kr (H.S.Y.); \\ mysong0823@gmail.com (M.Y.S.); dhl@jbnu.ac.kr (D.-H.L.); \\ 2 Department of Chemistry and Research Center for Bioactive Materials, Chonbuk National University, \\ Jeonju 54896, Korea \\ * Correspondence: slee026@jbnu.ac.kr; Tel.: +82-63-270-3412; Fax: +82-63-270-3407
}

Received: 27 October 2018; Accepted: 21 November 2018; Published: 26 November 2018

\begin{abstract}
Methane, an important greenhouse gas, has a 20-fold higher heat capacity than carbon dioxide. Earlier, through advanced spectroscopy and structural studies, the mechanisms underlying the extremely stable $\mathrm{C}-\mathrm{H}$ activation of soluble methane monooxygenase (sMMO) have been elucidated in Methylosinus trichosporium OB3b and Methylococcus capsulatus Bath. Here, sMMO components-including hydroxylase (MMOH), regulatory (MMOB), and reductase (MMOR)—-were expressed and purified from a type II methanotroph, Methylosinus sporium strain 5 (M. sporium 5), to characterize its hydroxylation mechanism. Two molar equivalents of MMOB are necessary to achieve catalytic activities and oxidized a broad range of substrates including alkanes, alkenes, halogens, and aromatics. Optimal activities were observed at $\mathrm{pH} 7.5$ for most substrates possibly because of the electron transfer environment in MMOR. Substitution of MMOB or MMOR from another type II methanotroph, Methylocystis species M, retained specific enzyme activities, demonstrating the successful cross-reactivity of M. sporium 5 . These results will provide fundamental information for further enzymatic studies to elucidate sMMO mechanisms.
\end{abstract}

Keywords: biocatalysts; biocatalytic reaction; Methylosinus sporium strain 5; soluble methane monooxygenase; $\mathrm{C}-\mathrm{H}$ activation; $\mathrm{O}_{2}$ activation

\section{Introduction}

Methanotrophic bacteria (methanotrophs) require methane gas $\left(\mathrm{CH}_{4}\right)$ as the sole carbon and energy source [1-3]. Hydroxylation of methane by methanotrophs is a crucial process that regulates the carbon cycle in ecological systems and can be applied in the fields of bioremediation and bioenergy [4-6]. Although carbon dioxide $\left(\mathrm{CO}_{2}\right)$ is the most abundant greenhouse gas, with 20-fold higher heat capacity, $\mathrm{CH}_{4}$ accelerates global warming [7,8]. The level of $\mathrm{CH}_{4}$ in ecological systems is regulated by methane monooxygenases (MMOs). The membrane-bound methane monooxygenase (pMMO) is expressed in most methanotrophs, including type I, II, and X, and recent studies have demonstrated detailed structures of this enzyme and its active sites [9-11]. The other type of $\mathrm{MMO}$, soluble methane monooxygenase (sMMO), has a non-heme diiron active site and is expressed in copper-limited conditions in limited type II and type X methanotrophs $[1,4,6,12]$. To achieve full biological conversion from methane to methanol, sMMO requires hydroxylase (MMOH), regulatory (MMOB), and reductase (MMOR) components, similar to other bacterial multi-component monooxygenase (BMM) superfamily members that utilize molecular oxygen $\left(\mathrm{O}_{2}\right)$, electrons $\left(\mathrm{e}^{-}\right)$, and protons $\left(\mathrm{H}^{+}\right)$, for the oxygenation of various substrates [13-17]. 
Type II methanotrophs, including Methylosinus and Methylocystis, and a type X methanotroph, such as Methylococcus capsulatus Bath, can express sMMO for hydroxylating methane $[1,18]$. The structures and functions of sMMO have been intensively investigated to elucidate the mechanisms using two methanotrophs, M. trichosporium OB3b and M. capsulatus Bath [16,19-21]. Hydroxylase from natural methanotrophs has been applied for enzymology studies in most reports because of solubility issues in heterologous systems. MMOH consists of $\alpha-, \beta-$-, and $\gamma$-subunits as a homodimer $\left(\alpha_{2} \beta_{2} \gamma_{2}\right)$, and the non-heme diiron active sites are positioned in the $\alpha$-subunit for the hydroxylation of methane $[20,21]$. Preliminary studies have shown that the absence of regulatory and/or reductase proteins decelerates the catalytic activities and that these component interactions are elaborately concerted for methane oxidation [13,22]. The oxidized $\mathrm{MMOH}\left(\mathrm{Fe}^{\mathrm{III}}-\mathrm{Fe}^{\mathrm{III}}\right)$ were reduced through electron transfer from MMOR to reduce the diiron active site. $\mathrm{O}_{2}$ activates $\mathrm{MMOH}_{\text {red }}\left(\mathrm{Fe}^{\mathrm{II}}-\mathrm{Fe}^{\mathrm{II}}\right)$ to get transient intermediates including $\mathrm{H}_{\text {peroxo }}$ and $\mathrm{Q}$ intermediates. Methane can be converted to methanol only through $\mathrm{Q}$ intermediate $[17,19]$. A structural study between $\mathrm{MMOH}$ and MMOB through X-ray crystallography proposed a pathway of substrates to the diiron active sites [23]. MMOB regulates gatekeeper residues, which control the opening of cavities for substrate access to the diiron active sites and pore regions.

M. sporium 5, a type II methanotroph, oxidizes methane to methanol through pMMO and sMMO [24-27]. The presence of a brown-black water-soluble pigment in nitrate mineral salt (NMS) medium is a distinct feature of M. sporium 5, although details of this mechanism require further studies [24,27]. Essential components of sMMO, including MMOH (248 kDa), MMOR (37.4 kDa), and MMOB (14.9 kDa), exhibit high sequence identity to those from other type II methanotrophs, including $M$. species $\mathrm{M}$ and $M$. trichosporium OB3b. When compared with $M$. sporium 5 , type $\mathrm{X}$ methanotrophs show relatively low sequence identity for MMOB (67\%), [2Fe-2S] cluster containing ferredoxin domain (MMOR-Fd, 58\%), and the FAD-binding domain (MMOR-FAD, 46\%) (Figure 1 and Figures S1-S3). The three subunits of MMOH are encoded by mmoX, mmoY, and $m m o Z$ and express $\alpha-$, $\beta$-, and $\gamma$-subunits, respectively. For the expression of MMOB, $m m \circ B$ is positioned between $m m o Y$ and $m m o Z$ in all sMMO-expressing methanotrophs. Alignment analyses show that the $\alpha$-subunit has high sequence identity with $\beta$ - and $\gamma$-subunits in both type II and type $X$ methanotrophs. MMOR consists of a MMOR-Fd domain at the $N$-terminus and a MMOR-FAD domain at the $C$-terminus, both of which are required for diiron reduction within the four-helix bundle at the $\alpha$-subunit of $\mathrm{MMOH}$. The reduced diferrous state $\left(\mathrm{Fe}^{\mathrm{II}}-\mathrm{Fe}^{\mathrm{II}}\right)$ can in turn activate $\mathrm{O}_{2}$ and initiate a catalytic cycle [28-31]. MMOB does not have any metal ions and coenzymes; however, this regulatory enzyme acts on the pore region near to the diiron active sites, containing the residues Thr213, Asn214, and Glu240, which are considered key regulators for the electron and/or proton transfer [23,32]. Catalytic activities are improved in the presence of MMOB and MMOH-MMOB complex, indicating that two MMOB molecules can bind to the hydroxylase component at the diiron active site, regulating methane hydroxylation [23]. The structural information between $\mathrm{MMOH}$ and MMOR is required to discover the electron transfer pathway that is crucial for turnover number. Recent studies have proposed that the ferredoxin domain of MMOR shares the binding site with MMOB located in the canyon region of MMOH for electron transfer [32].

In this study, M. sporium 5 was cultured in a tightly regulated NMS media by supplying methane and air to understand its growth and the expression levels of multi-component enzymes [24,26,27]. $\mathrm{MMOH}$ was found to be highly expressed in M. sporium 5 , and it was purified to evaluate its catalytic activities using diverse substrates. MMOB and MMOR were also expressed in E. coli via constructed plasmids to obtain highly purified enzymes. The successfully expressed and purified enzymes were utilized to measure specific enzyme activities (SEA), and these results showed that $M$. sporium 5 exhibits optimal activity at $\mathrm{pH}$ 7.5. The electron transfer environment of MMOR is crucial for the activity of sMMO, and different acidities may change the electron transfer environment. In vitro activity measurements demonstrated that alkanes, halogens, benzene, and toluene are oxidized through sMMO, and 2 mol equivalents of MMOB showed optimal activity. The pathways of methane oxidation through sMMO have been studied intensively in limited methanotrophic bacteria to date, but the 
present study provides fundamental information for elucidating these complicated and elaborate mechanisms of $\mathrm{C}-\mathrm{H}$ activation through structural and functional approaches from M. sporium 5.
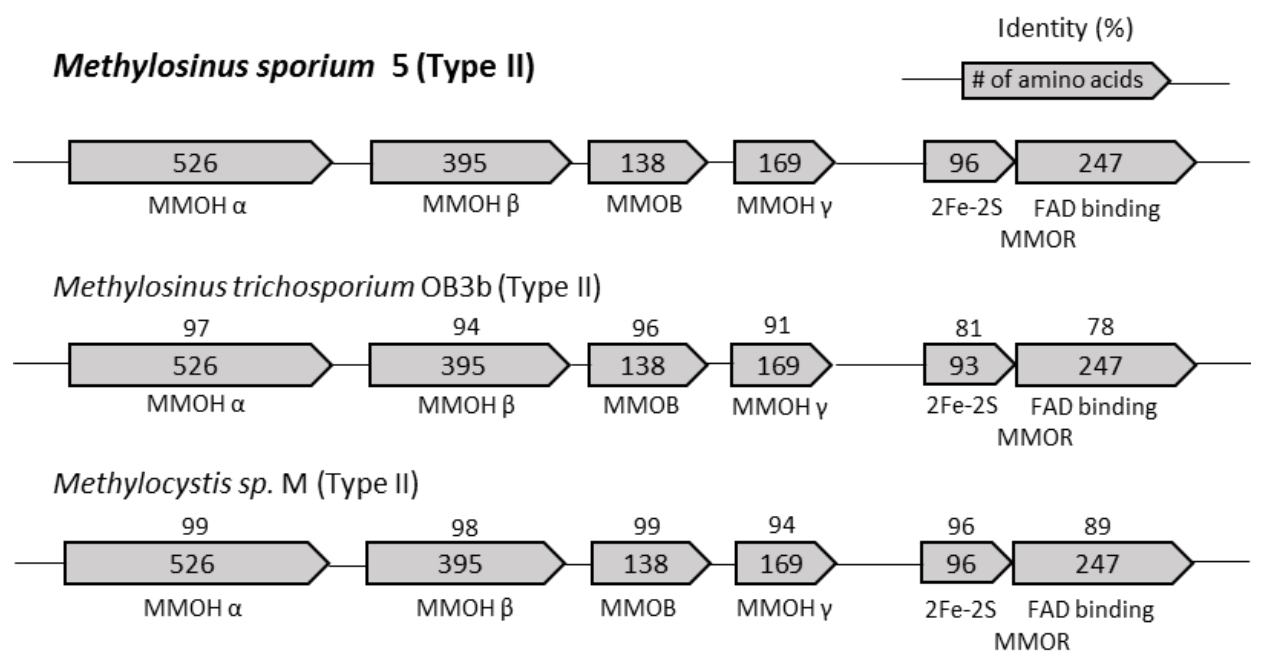

Methylococcus capsulatus Bath (Type X)

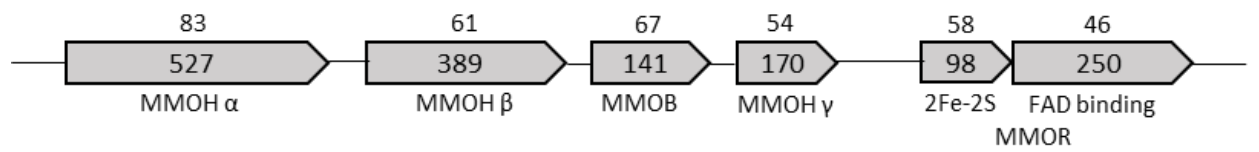

Figure 1. Multiple sequence alignments of amino acid sequences of soluble methane monooxygenase (sMMO) from type II and type X methanotrophs. Numbers above boxes represent the sequence identity to $\mathrm{sMMO}$ from M. sporium 5 , and numbers inside the box represent the number of amino acids in each enzyme and domain.

\section{Results and Discussion}

\subsection{Cultures of M. sporium 5 and Iron Concentration in NMS Medium}

For the expression of sMMO, M. sporium 5 was cultured in copper-limited NMS media, and results showed that using a feeding gas with ratio of $\mathrm{CH}_{4}$ :air $=1: 5$ yielded optimal cell growth. $M$. sporium 5 can proliferate to an optical density at $600 \mathrm{~nm}\left(\mathrm{OD}_{600}\right)$ of more than 10.0 under methane/air. Early studies demonstrated that $M$. sporium 5 produces a brown-black pigment during growth, and these phenotypes were also detected under certain growth conditions (Figure 2A and Figure S4) [24]. Cultures of M. sporium 5 showed white media at $\mathrm{OD}_{600}$ of approximately 1.0, which changed to a faint orange color beyond $\mathrm{OD}_{600}$ of 3.0. Additionally, the turbidity increased gradually by feeding with methane and air. The culture showed a brown-black color over $\mathrm{OD}_{600}$ of 8.0, and the color turned darker with increased cell growth (Figure 2A). As a control experiment, $M$. sporium 5 was cultured with different amounts of methane feeding, with once and twice per day in a rubber cap-sealed flask, and the growth was directly affected by methane amount (Figure S4). The one-time feeding culture proliferated to an $\mathrm{OD}_{600}$ of approximately 3.0, but two-times methane feeding resulted in an $\mathrm{OD}_{600}$ of 8.2 with brown-black pigmentation. This change in color is a characteristic feature of M. sporium 5 , and previous studies have proposed that this phenomenon is associated with the bioavailability of iron and the expression of sMMO [24,27]. 


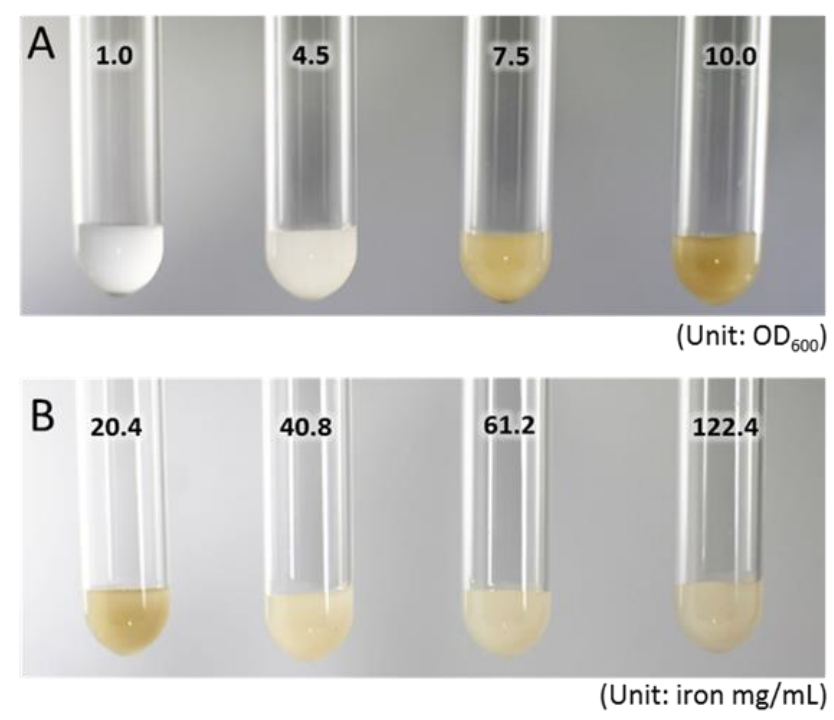

Figure 2. Pigment changes in M. sporium 5 cultured in NMS media during sMMO expression. (A) Normal media show color changes by increasing optical density at $600 \mathrm{~nm}\left(\mathrm{OD}_{600}\right.$, presented as numbers). The white pigment around $\mathrm{OD}_{600}$ of 1.0 changed to pink-orange around 3.0, and media changed to brown-black at $\mathrm{OD}_{600}$ values over 8.0. These changes were only observed in M. sporium 5 among other Methylosinus. (B) All cells were cultured to an $\mathrm{OD}_{600}$ of 8.5 in media with different iron concentrations. Normal NMS media for growing M. sporium 5 contained $20.4 \mathrm{mg} / \mathrm{mL}(1 \times)$ of iron and showed a dark brown color. Iron-supplemented NMS media $(40.8,61.2$, and $122.4 \mathrm{mg} / \mathrm{mL}$ of iron in media) did not show color changes upon increasing optical density.

Ali et al. showed that mutation of $m m o X$ results in different phenotypes based on the concentration of the iron supplemented in the agar plate, and they proposed that siderophores can be secreted from M. sporium 5 under iron-limited conditions to acquire iron from the extracellular medium [24]. To test this hypothesis, M. sporium 5 was cultured in iron-rich NMS media, and results suggested that iron is a key regulator of this pigment generation. M. sporium 5 was cultured to $\mathrm{OD}_{600}$ of 8.5 under normal iron concentrations (20.4 mg) in NMS media and iron-rich conditions (2-, 4-, and 6-fold higher iron concentration) to observe pigment changes (Figure 2B). Growth in normal NMS media resulted in brown-black color changes at $\mathrm{OD}_{600}$ of approximately 8.0, but $M$. sporium 5 cultured in iron-rich media did not exhibit brown-black color changes. These results provide an indirect evidence that the presence of iron at the diiron active site is required for the catalytic activity of the sMMO. Secretion of siderophores could be a defense mechanism of M. sporium 5 in growth condition of high bacterial concentrations and limited iron concentration. A possible explanation is that $M$. sporium 5 responds more sensitively than other type II methanotrophs because this methanotroph generates a brown-black pigment in response to a high cell:iron ratio (Figure 2 and Figure S4). Although transcriptomic studies of pMMO have proposed that iron requirements are achieved through the FecR iron sensor protein and FecR-like protein (fecR), biosynthetic pathways and secretion of siderophores from sMMO, including M. sporium 5, still need to be determined [33]. Another study proposed that this change in color may be caused by methanobactin. Following cell growth, the iron level decreases, whereas the amount of methanobactin increases; methanobactin is then secreted to the extracellular media to recruit copper and work as a 'copper-switch'. It has been demonstrated that in the absence of copper, methanobactin is able to bind to other transition metals, and this may be linked to the color change phenomenon [34].

\subsection{Expression and Purification of Hydroxylase from M. sporium 5}

Cultured M. sporium 5 was harvested to monitor expression levels of sMMO enzymes, and subunits of $\mathrm{MMOH}$, including the $\alpha-(59.9 \mathrm{kDa}), \beta-(45.2 \mathrm{kDa})$, and $\gamma$-subunits $(19.3 \mathrm{kDa})$, showed significant expression levels (Figure 3A). Sodium dodecyl sulfate-polyacrylamide gel electrophoresis 
(SDS-PAGE) demonstrated positive expression of MMOH, MMOB, and MMOR. The three subunits of $\mathrm{MMOH}$ were expressed highly compared with that of other essential components, including MMOB and MMOR. MMOH was purified from the extracts of native bacteria owing to its limited solubility in heterologous expression systems, such as E. coli, for further characterization. Preliminary studies showed that highly purified $\mathrm{MMOH}$ is essential to understand optimal activities and substrate hydroxylation by sMMO [35]. A study of Methylocystis species WI 14, a type II methanotroph, showed that SEA (mU/mg) of the cell extract improved by more than 10-fold by a three-step purification process using two anion-exchange columns and one size-exclusion column [35]. In enzyme activity assays using cell lysates, unpurified sMMO enzymes demonstrated that cell lysate exhibits low activity because of the presence of inhibitors and other metal components. Metal ions-such as $\mathrm{Zn}^{2+}, \mathrm{Cu}^{2+}$, and $\mathrm{Ni}^{2+}$-are considered as strong inhibitors of sMMO activity, although these metal ions were strongly controlled for the growth of $M$. sporium 5 through chelex resin in this study. Other possible inhibitory enzymes, such as MMOD (orfY), could inhibit its activity in the soluble portion of cell lysates [36]. For optimal activity of proteins from $M$. sporium 5 , essential enzymes were purified through a multi-step purification process. M. sporium 5 was cultured to an $\mathrm{OD}_{600}$ of approximately $8-10$ and purified through DEAE sepharose fast flow, Superdex 200, and Q sepharose resins to obtain highly purified $\mathrm{MMOH}$ (Figure 3B). The iron concentration of $\mathrm{MMOH}$ was determined through a ferrozine assay that indicated four iron atoms per $\mathrm{MMOH}$ (3.8-4.1 Fe/MMOH; Figure S5). Structural information has shown that this diiron active site is located $12 \AA$ below the surface with helices $\mathrm{E}$ and F, which consists of the pore region of $\mathrm{MMOH}$, and this region is considered as the electron transfer pathway and egress route of the product $[23,32,37]$. These results are in concurrence with the observation that purified $\mathrm{MMOH}$ contains proper iron-coordinated active sites and could be further applied for measuring catalytic activities.
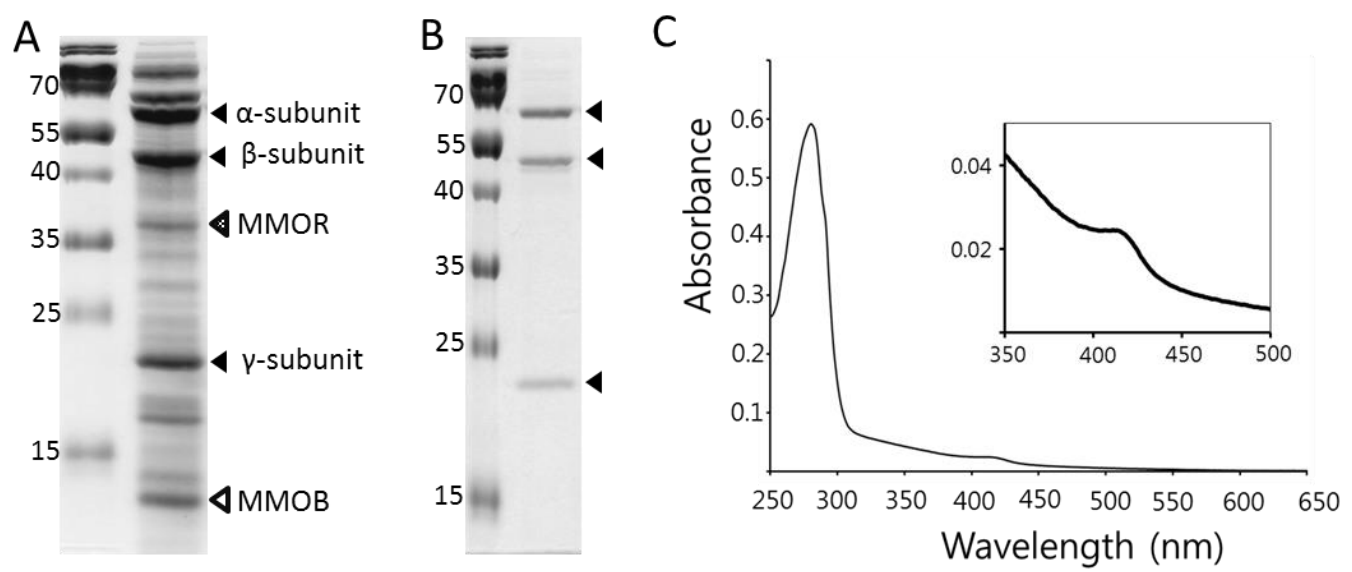

Figure 3. Expressed sMMO enzymes from M. sporium 5 and purified hydroxylase, regulatory, and reductase components. (A) Left lane represents the protein size-marker (unit: $\mathrm{kDa}$ ), and right lane represents the cell lysates from $M$. sporium 5 . $\mathrm{MMOH}$ including $\alpha-(59.9 \mathrm{kDa}), \beta-(45.2 \mathrm{kDa})$, and $\gamma-(19.3 \mathrm{kDa})$ subunits (black arrowheads) showed high expression in cell lysates. Two essential components, including reductase (MMOR; $37.4 \mathrm{kDa}$; a dotted arrowhead) and regulatory (MMOB; $14.9 \mathrm{kDa}$; an empty arrowhead) components, were also detected after expression. (B) Purified $\mathrm{MMOH}$ subunits after a three-step purification process are represented as arrows, and these highly purified enzymes were further applied to measure enzyme activities. (C) UV-visible absorption spectrum of purified MMOH from M. sporium 5 in $25 \mathrm{mM}$ sodium phosphate buffer at $\mathrm{pH}$ 7.0. Inset shows the enlarged spectrum from 350 to $500 \mathrm{~nm}$.

The UV-visible spectrum of purified $\mathrm{MMOH}$ is shown in Figure 3C, which exhibited optimal absorption at $280 \mathrm{~nm}$ with a calculated extinction coefficient of $561,220 \mathrm{~cm}^{-1} \mathrm{M}^{-1}$, and a weak charge transfer band was observed at approximately $390-430 \mathrm{~nm}$. Characterization of $\mathrm{MMOH}$ from M. trichosporium IMV3011, a type II methanotroph, showed that oxidized MMOH exhibits 
optimal intensity at $281 \mathrm{~nm}$ and weak absorption is detected at approximately 395-420 nm due to the oxo-bridged iron clusters [38]. The yellow color of $\mathrm{MMOH}$ arises from the charge transfer band around the $300-350 \mathrm{~nm}$ region, and spectral studies have evinced that this phenomenon is usually observed for the ( $\mu$-oxo)diiron(III) centers of the synthetic analogues. Preliminary reports have shown that the weak absorption spectrum from 400 to $500 \mathrm{~nm}$ by hydroxylase represents tyrosine radical formation and ligation, and M. sporium 5 showed these weak spectra, but $M$. trichosporium OB3b did not $[17,38-40]$.

\subsection{Expression and Purification of $M M O B$ and $M M O R$ from $\mathrm{E}$. coli}

MMOB does not have cofactors, such as metal ions and prosthetic groups, as shown by solution structures, although it affects $\mathrm{O}_{2}$ activation, product distribution, and reaction rates [14,17,22,41,42]. The complex structure of $\mathrm{MMOH}-\mathrm{MMOB}$ confirmed that this regulatory component interacts near diiron active sites to control the positions of the side chains from certain amino acids in $\mathrm{MMOH}$ that are crucial for catalytic activity [23]. The structure of MMOB was initially analyzed from M. capsulatus Bath [43], which showed an unstructured N-terminal tail (Met1-Ser35), well-folded core region (Asp36-Leu129) with seven $\beta$-strands and three $\alpha$-helices, and short $C$-terminal sequences (Met130-Ala141). The MMOH-MMOB complex demonstrated that the $N$-terminal long sequence binds to helices $\mathrm{H}$ and 4 in $\mathrm{MMOH}$ through specific hydrogen bonds and hydrophobic interactions. Thus, the $\mathrm{N}$-terminal tail is essential for catalytic activity and product hydroxylation. Because the expression level of MMOB is low from the native strain, a synthetic MMOB-encoding nucleotide sequence was inserted into pET30a plasmid ( $p E T 30 a-m m o B$, Figure S6A) to achieve high MMOB expression in E. coli. The purified MMOB showed a typical non-cofactor UV-visible absorption spectrum with maximal intensity at $280 \mathrm{~nm}$ with a calculated extinction coefficient of $\varepsilon_{280}=15,220 \mathrm{~cm}^{-1} \mathrm{M}^{-1}$ (Figure $4 \mathrm{~A}$ and Figure S6B). MMOB could be obtained at a concentration of $>10 \mathrm{mM}$ as it is highly soluble in $25 \mathrm{mM}$ phosphate and $100 \mathrm{mM} \mathrm{NaCl}$ buffer. These results imply that $\mathrm{MMOH}$ has reasonable solubility in bacterial cells, but MMOB has higher solubility compared to $\mathrm{MMOH}$.
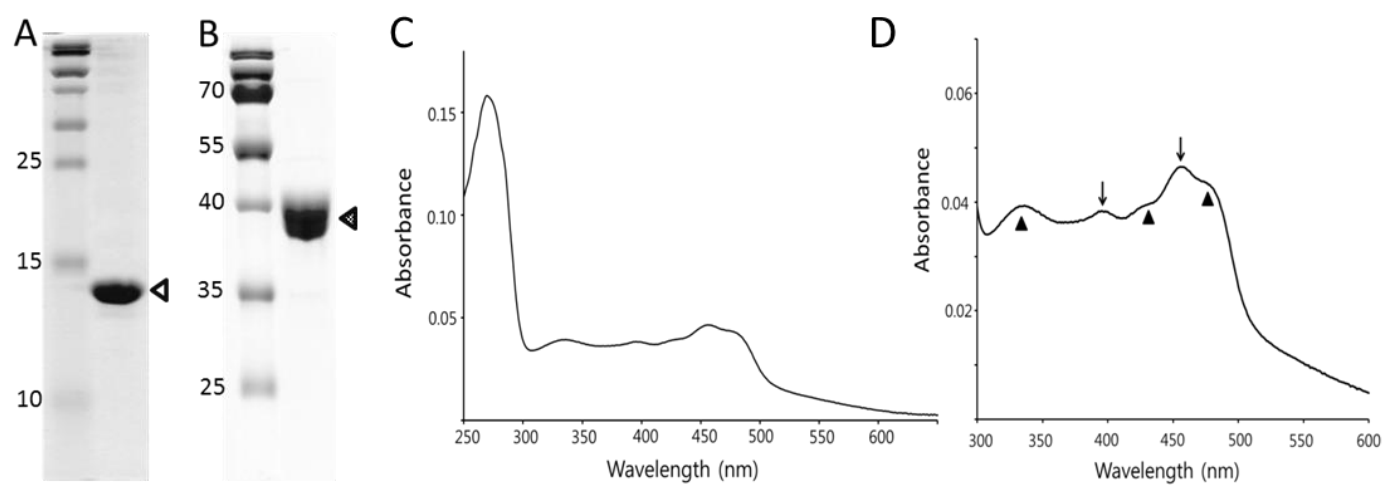

Figure 4. Purification of regulatory (MMOB) and reductase (MMOR) components. (A) Purified MMOB (empty triangle) through use of a recombinant plasmid ( $p E T 30 a-m m o B)$ expression in E. coli (unit: $\mathrm{kDa}$ ). (B) Purified MMOR (dotted triangle) through recombinant plasmid ( $p E T 30 a-m m o C$ ). (C) UV-visible spectrum of purified MMOR from M. sporium 5 showing the oxidized MMOR. (D) Enlarged UV-visible spectrum of MMOR from 300 to $600 \mathrm{~nm}$. Arrows and triangles represent the oxidized FAD-containing domain and [2Fe-2S] cluster domain, respectively.

MMOR is an essential component for the catalytic cycle owing to its electron transfer abilities, which are accomplished by FAD-containing and [2Fe-2S] cluster ferredoxin domains to reduce diiron active sites in $\mathrm{MMOH}[13,17,44,45]$. Kinetic studies have proposed that NADH binds to the MMOR-FAD in MMOH to transfer hydride, and the conformational change of NADH-FAD generates charge transfer bands $[28,29,46]$. The overall shape and volume of the MMOR-Fd are similar to those of the MMOB core region, suggesting that MMOB and MMOR share the 
binding sites of $\mathrm{MMOH}$ [11]. A synthetic nucleotide sequence encoding MMOR was inserted into pET30a and expressed in E. coli ( $p E T 30 a-m m o C$, Figure S7A) to achieve highly concentrated MMOR $\left(\varepsilon_{458}=21,200 \mathrm{~cm}^{-1} \mathrm{M}^{-1}\right)$ for enzymology assays and was purified using two-step anionic exchange columns and a single-step size exclusion column (Figure 4B). Ferrozine assay confirmed the presence of two irons (2.03-2.14 Fe/MMOR; Figure S7B) in the [2Fe-2S] cluster of MMOR-Fd. Two domains of MMOR, including MMOR-Fd and MMOR-FAD, show specific absorbance at approximately 300-600 nm (Figure 4C,D). Three major peaks were generated from MMOR at 334, 395, and $458 \mathrm{~nm}$ (indicated by arrows in Figure 4D), and these values were similar to those of MMOR from M. capsulatus Bath $(332,394$, and $458 \mathrm{~nm})$ and M. trichosporium OB3b [17,29]. Reported data from M. capsulatus Bath have shown that an oxidized MMOR-FAD generates peaks at 394 and $458 \mathrm{~nm}$ and the [2Fe-2S] cluster yields peaks at 332,418 , and $467 \mathrm{~nm}$. These results confirmed the existence of cofactors of MMOR.

\subsection{Activities of Essential Enzymes from M. sporium 5}

Purified enzymes were used to measure SEA of MMOH from M. sporium 5, and optimal activity ( $494 \pm 19 \mathrm{mU} / \mathrm{mg}$ ) was found with the substrate propylene in $25 \mathrm{mM}$ sodium phosphate buffer with 2 mol equiv. of MMOB to MMOH at $\mathrm{pH} 7.5$ (Figure 5A). MMOB affects the redox potential of $\mathrm{MMOH}$ and controls the formation of intermediates that finally alters product distribution significantly in $M$. trichosporium OB3b $[22,47,48]$. Hydroxylation of $\mathrm{NO}_{2}$-benzene produces $m-\mathrm{NO}_{2}$-phenol as the major product ( $>90 \%$ ) in the absence of $\mathrm{MMOB}$, but 2 mol equiv. of $\mathrm{MMOB}$ with $\mathrm{MMOH}$ produce $89 \%$ $p-\mathrm{NO}_{2}$-phenol [22]. Structural studies of the MMOH-MMOB complex demonstrated that 2 mol equiv. of MMOB bind to $\mathrm{MMOH}$ symmetrically to each $\alpha \beta \gamma$ promoter to regulate the substrate pathways through hydrophobic cavities. This study also confirmed that less than 2 mol equiv. of MMOB are not sufficient for optimal activity of $\mathrm{MMOH}\left(\alpha_{2} \beta_{2} \gamma_{2}\right)$ and 3 mol equiv. of MMOB may block the interaction of MMOR to MMOH for efficient electron transfer. The activities of 1 and 3 mol equiv. of $\mathrm{MMOB} / \mathrm{MMOH}$ showed reduced SEA by more than $35 \%$ and $20 \%$, respectively. The ratio of $\mathrm{MMOR} / \mathrm{MMOH}$ in the presence of 2 mol equiv. of MMOB influenced SEA of $\mathrm{MMOH}$, but more than 1 mol equiv. of MMOR did not significantly increase MMOH activity (Figure S8). SEA of 2 mol equiv. of MMOR ( $515 \pm 15 \mathrm{mU} / \mathrm{mg})$ was similar to that of $1 \mathrm{~mol}$ equiv. of MMOR $(494 \pm 19 \mathrm{mU} / \mathrm{mg})$. The proposed mechanisms of sMMO demonstrated that MMOB binds to MMOH for intermediate generation, but MMOR/MMOH interaction is required for a relatively short time compared with that of MMOB in the resting states of $\mathrm{MMOH}\left(\mathrm{Fe}^{\mathrm{III}}-\mathrm{Fe}^{\mathrm{III}}\right)$, and 1 mol equiv. of MMOR was applied to measure activity in this study.

A report demonstrated that highly purified MMOH exhibits SEA of $185 \mathrm{mU} / \mathrm{mg}$ because all multi-components are not successfully purified from M. sporium 5 [26]. Our results demonstrated SEA of $28 \mathrm{mU} / \mathrm{mg}$ in the absence of MMOB (Figure 5B); reports have also proposed that MMOB is essential for the activity because it can improve activity by more than 20-fold. Another type II methanotroph, M. trichosporium IMV 3011, exhibits SEA of $603.6 \mathrm{mU} / \mathrm{mg}$, and the optimal activity is obtained at $\mathrm{pH}$ 7.2 in $25 \mathrm{mM}$ Tris- $\mathrm{HCl}$ buffer [38]. Highly purified enzymes are required for sMMO studies, possibly because of other components that are co-expressed in methanotrophs. Although the specific function of MMOD (orf $Y$ ) has yet to be uncovered, it is considered as a catalytic inhibitor of MMOH. In addition, $\mathrm{MMOH}$ stability is a crucial factor for achieving high SEA in sMMO, and $\mathrm{Fe}\left(\mathrm{NH}_{4}\right)_{2}\left(\mathrm{SO}_{4}\right)_{2}$, cysteine, dithiothreitol (DTT), and sodium thioglycolate are added to maintain the stability of cell extracts during purification $[35,49]$.

The FAD-containing domain (MMOR-FAD; MMOR residues 97-343) provides crucial clues to understand these activity changes at different $\mathrm{pH}$ conditions (Figure 6). MMOR-FAD was expressed using the constructed $p E T 30 a-m m o C-F A D$ plasmid (Figure S9) and was purified to measure the UV-visible absorption spectra in solutions with different acidities. MMOR-FAD yielded distinct peaks at $396 \mathrm{~nm}$ and $456 \mathrm{~nm}$ from $\mathrm{pH} 6$ to 8 (Figure 6). The absorption ratio $\left(\mathrm{A}_{270} / \mathrm{A}_{458}\right)$ of MMOR-FAD was approximately 6.8, implying that flavin co-factors are fully complemented in the purified MMOR [29]. Oxidized MMOR-FAD spectra in an earlier study proposed that buffer acidity changes the absorption 
at $394 \mathrm{~nm}$ because of the subtle perturbation of the flavin-binding site in MMOR, and alterations of hydrogen bonding or solvent accessibility occur due to the conformational changes of isoalloxazine in FAD [29]. The intensity at $396 \mathrm{~nm}$ increased up to $\mathrm{pH} 7.0$, and absorption reduced at $\mathrm{pH} 8.0$. The absorption ratio between 458 and $396 \mathrm{~nm}\left(\mathrm{~A}_{458} / \mathrm{A}_{396}\right)$ changed from 1.29 at $\mathrm{pH} 4.0$ to 1.4 at $\mathrm{pH} 8.0$, and these results agree with the optical spectrum of oxidized flavin, which shows absorption changes based on acidity. Lowest activity was measured at around pH 5.0 (Figure 5; $72 \pm 5.8 \mathrm{mU} / \mathrm{mg}$ ), and MMOR-FAD showed the lowest absorption at $396 \mathrm{~nm}$ and absorption at $456 \mathrm{~nm}$ at $\mathrm{pH} 4-5$ (Figure 6). The spectra showed distinct peaks at approximately $456 \mathrm{~nm}$ at pH 6-8, and a small peak was observed at approximately $476 \mathrm{~nm}$, similar to the peak observed at the same $\mathrm{pH}$ range usually detected for oxidized FAD, but these absorptions were not observed at low $\mathrm{pH}$ values. These results indicated that electron transfer thorough the flavin cofactor is an important aspect for diiron activation. The reported optical spectra of MMOR-FAD from M. capsulatus Bath demonstrated that absorption decreases at $500 \mathrm{~nm}$ and absorption increases gradually at $450 \mathrm{~nm}$ by changing the $\mathrm{pH}$ from 5 to 9 .
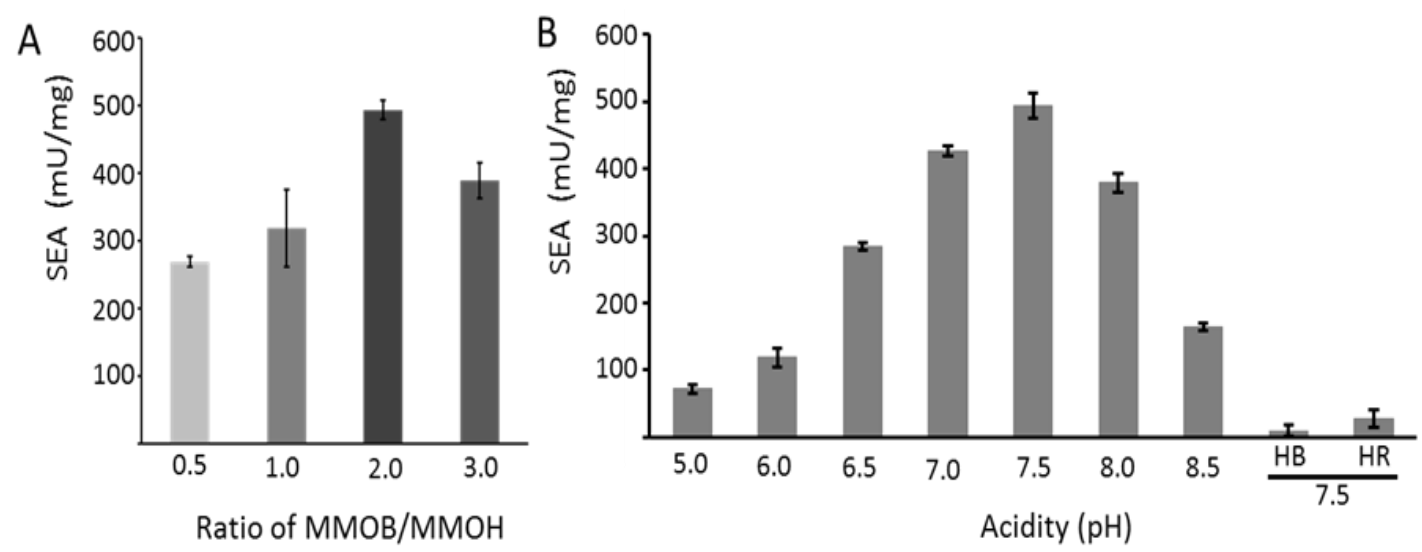

Figure 5. SEA of purified sMMO, including MMOH, MMOB, and MMOR, from M. sporium 5. sMMO converts propylene to propylene oxide in the presence of NADH. (A) Purified MMOH (1.0 mol equiv.), MMOR (1.0 mol equiv.), and different mole ratios of MMOB were incubated with propylene in $25 \mathrm{mM}$ sodium phosphate buffet at $30^{\circ} \mathrm{C}$ at $\mathrm{pH}$ 7.5. (B) The maximal epoxidation activity (mol ratio of MMOH:MMOB:MMOR = 1:2:1) of propylene was monitored at different acidities, and control experiments confirmed that MMOB and MMOR are essential enzymes for catalytic activity. $\mathrm{HB}$ and $\mathrm{HR}$ represent the absence of MMOR $(\mathrm{HB})$ and MMOB $(\mathrm{HR})$, respectively. All experiments were performed at least three times, and error bars represent standard deviations.

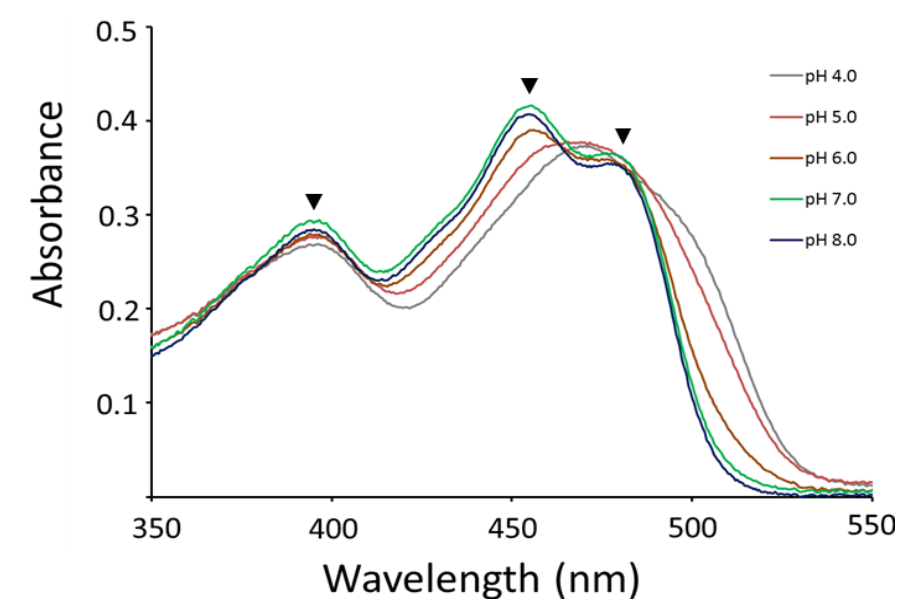

Figure 6. UV-visible absorption spectra of oxidized MMOR-FAD depending on the $\mathrm{pH}$. Optical spectra were measured of purified MMOR-FAD (97-343 residues of MMOR from M. sporium 5) at different acidity values. Filled triangles represent flavin absorptions at 396, 456, and $476 \mathrm{~nm}$. 


\subsection{Oxidation of Alkane, Halogen, and Aromatic Compounds}

One interesting aspect of sMMO of the BMM superfamily members is the oxidation ability of various substrates, including alkanes, alkenes, aromatics, heterocyclics, and chlorinated compounds [4,14,50-52]. Dalton et al. showed that cell extracts of $M$. capsulatus Bath can hydroxylate $\mathrm{C}_{1}-\mathrm{C}_{8}$ alkanes and aromatic compounds, such as benzene and toluene [42]. Hydroxylation ability of purified sMMO components from $M$. sporium 5 was measured with alkanes, including pentane and heptane (Figure 7A). SEA results showed that pentane $(102 \pm 4.6 \mathrm{mU} / \mathrm{mg})$ and heptane $(109 \pm 9.2 \mathrm{mU} / \mathrm{mg})$ were hydroxylated by sMMO, and the overall activity toward heptane was slightly higher, indicating that the activity of sMMO toward $n$-alkanes decreased sharply from pentane to octane owing to the substrate size. The rate of substrate access to the diiron active site for hydroxylation is lowered because this substrate moves along the proposed pathways from cavity 3 to cavity $1[23,53]$. These results also suggested that non-specific hydroxylation of substrates occurs in $n$-alkanes because oxidation of alkanes through sMMO generates different hydroxylated products. n-Alkanes can be oxidized at the primary and secondary alkyl with different product ratios, although secondary alkyl hydroxylation is the major product in most cases [42]. Optimal enzyme activity was observed at $\mathrm{pH} 7.5$ for most substrates in this study, but heptane showed slightly better activity at $\mathrm{pH} 7.5$ $(128 \pm 4.1 \mathrm{mU} / \mathrm{mg})$ compared with that at $\mathrm{pH} 7.0(109 \pm 9.2 \mathrm{mU} / \mathrm{mg})$. These results also support that sMMO is a non-specific enzyme and that oxidation is not tightly regulated because hydroxylation of substrates produces different products. sMMO extracts from $M$. capsulatus Bath hydroxylate pentane to produce pentan-1-ol (27\%), pentan-2-ol (69\%), and pentan-3-ol $(<3 \%)$, and other alkanes, including hexane, heptane, and octane, to yield non-specific hydroxylated products [42]. Complex formation among $\mathrm{MMOH}, \mathrm{MMOB}$, and MMOR may occur slightly differently based on the acidity of the solution, which would affect product formation and turnover number.
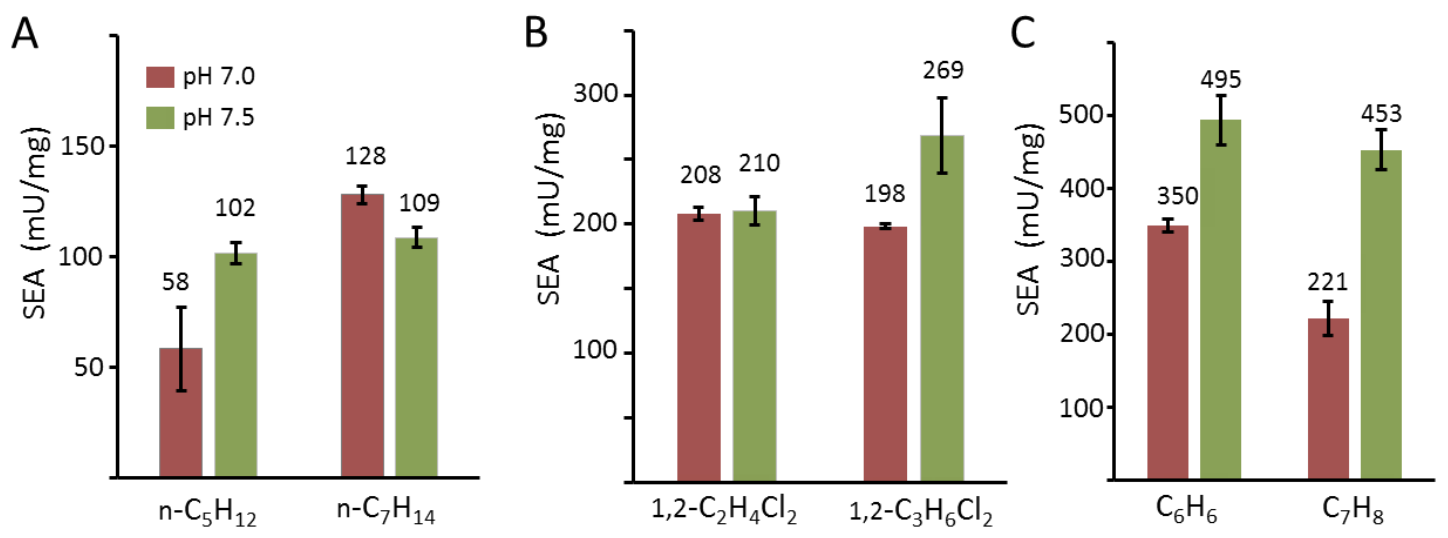

Figure 7. Soluble MMO from M. sporium 5 oxidized various substrates, including alkane, halogen, and aromatic compounds. (A) Normal pentane $\left(\mathrm{n}-\mathrm{C}_{5} \mathrm{H}_{12}\right)$ and normal heptane $\left(\mathrm{n}-\mathrm{C}_{7} \mathrm{H}_{14}\right)$ harbor more carbon atoms than propylene. The activities were measured at $340 \mathrm{~nm}$ by measuring NADH degradation. (B) Halogen compounds, including 1,2-dichloroethane $\left(1,2-\mathrm{C}_{2} \mathrm{H}_{4} \mathrm{Cl}_{2}\right)$ and 1,2-dichloropropane (1,2- $\left.\mathrm{C}_{3} \mathrm{H}_{6} \mathrm{Cl}_{2}\right)$, were oxidized by sMMO. (C) Measurement of specific enzyme activity with benzene $\left(\mathrm{C}_{6} \mathrm{H}_{6}\right)$ and toluene $\left(\mathrm{C}_{7} \mathrm{H}_{8}\right)$. NADH consumption was not observed in the absence of substrates. SEA represents specific enzyme activity ( $n=3$, avg \pm s.d.).

Hydroxylation of chlorinated or aromatic compounds is a fascinating ability because toxic and environmentally hazardous materials are converted to non-toxic or less-toxic products [14,42]. Owing to these reasons, sMMO is investigated for application in the field of environmental enzymology for hydroxylation of chlorinated and aromatic compounds. Chlorinated compounds, including 1,1-dichloroethane (1,1- $\left.\mathrm{C}_{2} \mathrm{H}_{4} \mathrm{Cl}_{2}\right)$ and 1,1-dichloropropane (1,1- $\left.\mathrm{C}_{3} \mathrm{H}_{6} \mathrm{Cl}_{2}\right)$, and aromatic compounds, including benzene and toluene, were incubated with the sMMO system (Figure 7B,C). These results showed that sMMO from M. sporium 5 did not exhibit substrate specificity like other sMMOs from 
different methanotrophs. The chlorinated compounds had lower SEA compared with propylene epoxidation but benzene and toluene showed almost similar activities to that of propylene at $\mathrm{pH}$ 7.5. These results suggest that sMMO from $M$. sporium 5 has lower substrate specificity to aromatic compounds. There is no direct evidence on how these large substrates get access to the diiron active sites; however, previous results demonstrated that a different molar ratio of MMOB affects the product distributions [22]. The cavities of sMMO allow small substrate transport pathways, such as methane, when crystals were compressed with Xe and large hydrophobic cavities were not developed like other BMM superfamily members. The relatively good enzyme activities in benzene by sMMO may be due to the structural flexibility near the diiron active sites in M. sporium 5 compared to other organisms.

\section{Material and Methods}

\subsection{General Materials and Chemicals}

M. sporium 5 (ATCC35069) was obtained from the American Type Culture Collection (ATCC), and nitrate mineral salts (NMS) media (ATCC 1306) were prepared based on the manufacturer's protocol. All chemicals included in NMS media were purchased from Sigma-Aldrich (St. Louis, MO, USA). pET-30a $(+)$ and BL21(DE3) were purchased from EMD Millipore, and DH5 $\alpha(\mathrm{DE} 3)$ was purchased from New England Biolabs. Synthetic nucleotides ( $m m o C$ and mmoB from M. sporium 5 and M. species $\mathrm{M}$ and primers (Table S1) were purchased and sequenced from Cosmogenetech. DNA extraction and purification were performed with a FavorPrep kit (Favorgen), and images were obtained from an E-Gel Imager System with UV Light Base (Thermo Fisher). Luria Broth (Lennox, powder microbial growth medium) was purchased from Sigma-Aldrich. Methane (99.9\%), argon (99.9\%), and propylene (99.5\%) gases were purchased from Hankook Special Gases. All columns were attached to an ATKA Pure 25L, fast protein liquid chromatograph (GE Healthcare Life Science) to purify proteins. All chemicals were purchased from Sigma-Aldrich (St. Louis, MO, USA) and Alfa Aesar unless indicated otherwise.

\subsection{Culturing M. sporium 5 and $M M O H$ Purification}

M. sporium 5 was incubated in copper-limited NMS media at $30{ }^{\circ} \mathrm{C}$ in a 4 -L rubber cap-sealed baffled Erlenmeyer flask at $220 \mathrm{rpm}$ to achieve an $\mathrm{OD}_{600}$ of 8-10 with a methane:air (v/v) ratio of 1:5. $\mathrm{pH}$ was adjusted to 7.0 with $100 \mathrm{mM} \mathrm{NaOH}$ and $100 \mathrm{mM} \mathrm{HCl}$. The optical density of grown cultures was measured at $600 \mathrm{~nm}$ using a UV-visible spectrometer (Cary 60 Agilent). Normal NMS medium contained $20.4 \mathrm{mg} / \mathrm{mL}$ iron during the cell culture, and additional iron was added to the iron-rich NMS media using $\left(\mathrm{NH}_{4}\right)_{2} \mathrm{Fe}\left(\mathrm{SO}_{4}\right)_{2} \cdot 6 \mathrm{H}_{2} \mathrm{O}$ to attain final concentrations of $40.8,61.2$, or $122.4 \mathrm{mg} / \mathrm{mL}$ of iron. The images of media with different iron concentrations were obtained when $\mathrm{OD}_{600}$ was 8.5 (Figure 2B).

M. sporium 5 cells were harvested by centrifugation $(11,300 \times g$, $20 \mathrm{~min}$; Supra $22 \mathrm{~K}$ model, Hanil Science) at $4{ }^{\circ} \mathrm{C}$. Cell pellet from $5 \mathrm{~L}$ of culture was suspended in $25 \mathrm{mM}$ MOPS, $25 \mathrm{mM} \mathrm{NaCl}, 8 \mathrm{mM}$ sodium thioglycolate, $2 \mathrm{mM}$ L-cysteine, $200 \mu \mathrm{M}\left(\mathrm{NH}_{4}\right)_{2} \mathrm{Fe}\left(\mathrm{SO}_{4}\right)_{2} \cdot 6 \mathrm{H}_{2} \mathrm{O}, 5 \mathrm{mM} \mathrm{MgCl}, 0.25 \mu \mathrm{L} / \mathrm{mL}$ DNase, and $0.04 \mathrm{mg} / \mathrm{mL}$ phenylmethane sulfonyl fluoride (PMSF) at $\mathrm{pH}$ 6.5. The dissolved suspension was disrupted by sonication at $4{ }^{\circ} \mathrm{C}(\mathrm{CV} 334$ model, Sonics). The cell lysate was centrifuged at $30,000 \times g$ for $45 \mathrm{~min}$ at $4{ }^{\circ} \mathrm{C}$ (Combi 514R model, Hanil Science), and the supernatant was carefully decanted and filtered through a $0.22-\mu \mathrm{m}$ membrane (Merck Millipore).

The filtrate was loaded onto a DEAE sepharose fast flow column (GE Healthcare) packed in an XK 50/60 column (GE Healthcare) and equilibrated with Buffer A (25 mM MOPS at pH 6.5 containing $8 \mathrm{mM}$ sodium thioglycolate, $2 \mathrm{mM}$ L-cysteine, $200 \mu \mathrm{M}\left(\mathrm{NH}_{4}\right)_{2} \mathrm{Fe}\left(\mathrm{SO}_{4}\right)_{2} \cdot 6 \mathrm{H}_{2} \mathrm{O}, 5 \mathrm{mM}$ $\mathrm{MgCl}_{2}$, and $50 \mathrm{mM} \mathrm{NaCl}$ ). After loading the supernatant, the column was equilibrated with $1000 \mathrm{~mL}$ of buffer $\mathrm{A}$ and eluted with $2000 \mathrm{~mL}$ of buffer $\mathrm{A}$ in a linear gradient from $0-500 \mathrm{mM} \mathrm{NaCl}$ at a flow rate of $1.0 \mathrm{~mL} / \mathrm{min}$. MMOH-containing fractions (Buffer A contained around $250 \mathrm{mM} \mathrm{NaCl}$ ) were resolved by SDS-PAGE (Bio-Rad) and stained with Coomassie Brilliant Blue to confirm the presence of $\mathrm{MMOH}$. MMOH-containing fractions were concentrated with a molecular weight cut-off 
membrane (Amicon ultracentrifugal filter $30 \mathrm{kDa}$; Merck Millipore). The concentrated MMOH was loaded onto a Superdex 200 column (GE Healthcare) packed in an XK26/70 column (GE Healthcare), equilibrated with $25 \mathrm{mM}$ MOPS, containing $8 \mathrm{mM}$ sodium thioglycolate, $2 \mathrm{mM}$ L-cysteine, $200 \mu \mathrm{M}$ $\left(\mathrm{NH}_{4}\right)_{2} \mathrm{Fe}\left(\mathrm{SO}_{4}\right)_{2} \cdot 6 \mathrm{H}_{2} \mathrm{O}, 200 \mathrm{mM} \mathrm{NaCl}, 1 \mathrm{mM} \mathrm{DTT}$, and 5\% glycerol. MMOH-containing fractions were resolved with SDS-PAGE and concentrated with a molecular weight cut-off membrane ( $30 \mathrm{kDa})$. The concentrated sample was loaded onto a $Q$ sepharose fast flow column packed in an XK 26/40 column (GE Healthcare) with Buffer B (25 mM MOPS containing $1 \mathrm{mM} \mathrm{DTT,} 50 \mathrm{mM} \mathrm{NaCl}$, and $10 \%$ glycerol). $\mathrm{MMOH}$ was eluted with Buffer B with a linear gradient from 0 to $500 \mathrm{mM} \mathrm{NaCl}$. Selected fractions after SDS-PAGE were concentrated through an Amicon ultracentrifugal filter to obtain $\mathrm{MMOH}$ with $>95 \%$ purity and stored at $-88^{\circ} \mathrm{C}$ before application for further experiments.

\subsection{Construction of $m m o B$ and $m m o C$ from $M$. sporium 5 and $M$. species $M$}

A synthetic $m m o B$ nucleotide sequence in a pUC18 vector ( $p U C 18-m m o B$, Cosmogentech) was amplified in DH5 $\alpha$ (DE3) and then extracted using a QIAprep Spin Miniprep kit (QIAGEN). mmoB (417 bp) was amplified from $p U C 18-m m o B$ by PCR using two oligonucleotide-primers, $m m o B-M-F d$ and $m m o B-M-R v$ (Table S1). Amplified $m m o B$ was digested with NdeI and HindIII (Takara) and was then inserted into pET30a(+) to construct $p E T 30 a-m m o B$ (Figure S6). mmoB from M. species $\mathrm{M}$ was constructed using the same protocols with two nucleotide primers, $m m o B-M M-F d$ and $m m o B-M M-R v$ (Table S1).

A synthetic $m m o C$ nucleotide sequence in a pUC18 vector ( $p$ UC18-mmoC, Cosmogentech) was amplified in DH5 $\alpha$ (DE3) and extracted using a QIAprep Spin Miniprep kit. mmoC (1,032 bp) was amplified in $p U C 18-m m o C$ by PCR using two oligonucleotide primers, $m m o C-M-F d$ and $m m o C-M-R v$ (Table S1). Amplified mmoC was digested with NdeI and HindIII and was then inserted into pET30a(+) to construct $p E T 30 a-m m o C$ (Figure S7). mmoC from $M$. species $\mathrm{M}$ was constructed using the same protocol with two nucleotide primers, $m m o C-M M-F d$ and $m m o C-M M-R v$ (Table S1).

$m m o C-F A D(744 \mathrm{bp})$ was amplified in $p U C 18-m m o C$ by PCR using two oligonucleotide primers, $m m o C-F A D-M-F d$ and mmoC-FAD-M-Rv (Table S1). Amplified mmoC was digested with NdeI and HindIII and was then inserted into pET30a(+) to construct $p E T 30 a-m m o C$ (Figure S9).

\subsection{Expression and Purification of $M M O B$}

The constructed $p E T 30 a-m m o B$ was transformed into BL21 (DE3) cells (Novagen) and cultured in LB medium containing $50 \mu \mathrm{g} / \mathrm{mL}$ kanamycin at $37^{\circ} \mathrm{C}$ until mid-log phase. Cell cultures were cultured until $5 \mathrm{~h}$ post-induction with $1.0 \mathrm{mM}$ isopropyl $\beta$-D-1-thiogalactopyranoside (IPTG) before harvesting by centrifugation $\left(11,300 \times g\right.$ for $20 \mathrm{~min}$ at $\left.4{ }^{\circ} \mathrm{C}\right)$. The cell pellets were suspended in $25 \mathrm{mM}$ phosphate at pH 6.0, $75 \mathrm{mM} \mathrm{NaCl}, 1 \mathrm{mM} \mathrm{Na}_{2}$-EDTA, $1 \mathrm{mM} \mathrm{DTT}, 5 \mathrm{mM} \mathrm{MgCl}_{2}, 0.25 \mu \mathrm{L} / \mathrm{mL}$ DNase $\mathrm{I}$, and $0.04 \mathrm{mg} / \mathrm{mL}$ PMSF, and then suspensions were disrupted by sonication at $4{ }^{\circ} \mathrm{C}$. The lysed cells were centrifuged at $26,000 \times g$ at $4{ }^{\circ} \mathrm{C}$ for $60 \mathrm{~min}$, and supernatant was carefully decanted and filtered through a $0.22-\mu \mathrm{m}$ membrane. The filtrate was loaded onto a $\mathrm{Q}$ sepharose fast flow column packed in a XK 26/40 column equilibrated in $25 \mathrm{mM}$ phosphate ( $\mathrm{pH} 6.0$ ), containing $75 \mathrm{mM} \mathrm{NaCl}$, $1 \mathrm{mM} \mathrm{Na}_{2}$-EDTA, $1 \mathrm{mM} \mathrm{DTT}$, and 5\% glycerol (Buffer C). After loading the supernatant, the column was washed with $700 \mathrm{~mL}$ of buffer $\mathrm{C}$ with a linear gradient from 0 to $500 \mathrm{mM} \mathrm{NaCl}$ at a flow rate of $1.0 \mathrm{~mL} / \mathrm{min}$. MMOB-containing fractions were collected and analyzed by SDS-PAGE and were then concentrated using a molecular weight cut-off membrane $(10 \mathrm{kDa})$. Concentrated MMOB was loaded onto a Superdex 75 column (GE Healthcare) packed in a XK16/70 column equilibrated in Buffer C. MMOB-containing fractions were collected and analyzed by SDS-PAGE and were then concentrated using a cut-off membrane to obtain MMOB (colorless solution) with $>95 \%$ purity, which was stored at $-88^{\circ} \mathrm{C}$ before application for further experiments. 


\subsection{Expression and Purification of MMOR and MMOR-FAD}

The constructed $p E T 30 a-m m o C$ or $p E T 30 a-m m o C-F A D$ was transformed into BL21 (DE3) cells (Novagen) and cultured in LB medium, containing $50 \mu \mathrm{g} / \mathrm{mL}$ kanamycin and $500 \mu \mathrm{M}$ $\left(\mathrm{NH}_{4}\right)_{2} \mathrm{Fe}(\mathrm{SO} 4)_{2} \cdot 6 \mathrm{H}_{2} \mathrm{O}$, at $37{ }^{\circ} \mathrm{C}$ until mid-log phase. Cell cultures were incubated for $12 \mathrm{~h}$ post-induction with $0.5 \mathrm{mM} \mathrm{IPTG}$ at $25^{\circ} \mathrm{C}$ at $200 \mathrm{rpm}$ before harvesting by centrifugation $(11,300 \times \mathrm{g}$ for $20 \mathrm{~min}$ at $\left.4{ }^{\circ} \mathrm{C}\right)$. Cell pellets were suspended in $25 \mathrm{mM}$ MOPS at pH 6.5, containing $25 \mathrm{mM} \mathrm{NaCl}, 8$ $\mathrm{mM}$ sodium thioglycolate, $2 \mathrm{mM}$ L-cysteine, $200 \mu \mathrm{M}\left(\mathrm{NH}_{4}\right)_{2} \mathrm{Fe}\left(\mathrm{SO}_{4}\right)_{2} \cdot 6 \mathrm{H}_{2} \mathrm{O}, 5 \mathrm{mM} \mathrm{MgCl}, 1$ unit $/ \mathrm{mL}$ DNase I, and 0.2 mM PMSF, and were disrupted by sonication. The lysed cells were centrifuged at $26,000 \times g$ at $4{ }^{\circ} \mathrm{C}$ for $40 \mathrm{~min}$, and the supernatant was carefully decanted and filtered through a $0.22 \mu \mathrm{m}$ membrane. The filtrate was loaded onto a DEAE sepharose fast flow column packed in XK $50 / 40$ column equilibrated in $25 \mathrm{mM}$ MOPS ( $\mathrm{pH}$ 6.5), containing $8 \mathrm{mM}$ sodium thioglycolate, $2 \mathrm{mM}$ L-cysteine, $200 \mu \mathrm{M}\left(\mathrm{NH}_{4}\right)_{2} \mathrm{Fe}\left(\mathrm{SO}_{4}\right)_{2} \cdot 6 \mathrm{H}_{2} \mathrm{O}$, and $25 \mathrm{mM} \mathrm{NaCl}$ (Buffer D). After loading the supernatant, the column was washed with $1 \mathrm{~L}$ of buffer $\mathrm{D}$ with a linear gradient from 0 to $600 \mathrm{mM} \mathrm{NaCl}$ at a flow rate of $1.5 \mathrm{~mL} / \mathrm{min}$. MMOR-containing fractions were collected and analyzed by SDS-PAGE and were then concentrated using a molecular weight cut-off membrane $(10 \mathrm{kDa})$. Concentrated MMOR was loaded onto a $Q$ sepharose column (GE Healthcare) packed in XK26/40 column equilibrated in $25 \mathrm{mM}$ MOPS (pH 6.5), containing $50 \mathrm{mM} \mathrm{NaCl}, 1 \mathrm{mM}$ DTT, and 10\% glycerol (Buffer E). After loading the supernatant, the column was washed with $1.2 \mathrm{~L}$ of buffer $\mathrm{E}$ with a linear gradient from 0 to $500 \mathrm{mM} \mathrm{NaCl}$ at a flow rate of $1.5 \mathrm{~mL} / \mathrm{min}$. MMOR-containing fractions were collected and analyzed by SDS-PAGE and were then concentrated using a cut-off membrane to obtain MMOR (red-brown solution) with $>95 \%$ purity, which was stored at $-88^{\circ} \mathrm{C}$ before application for further experiments.

\subsection{Measurement of SEA with Various Substrates}

MMOH $(1.0 \mu \mathrm{M})$, MMOB $(2.0 \mu \mathrm{M})$, and $1.0 \mu \mathrm{M}$ MMOR were added to $25 \mathrm{mM}$ phosphate and $10 \mathrm{mM} \mathrm{NaCl}$ (Buffer F) and bubbled with propylene (Hankook Special Gas) for $20 \mathrm{~min}$. Other substrates-including pentane, heptane, 1,2-dichloroethane, 1,2-dichloropropane, benzene, and toluene-were added to buffer $\mathrm{F}$ to obtain a final concentration of $20 \mathrm{mM}$. The whole mixture was incubated at $30{ }^{\circ} \mathrm{C}$ at the indicated $\mathrm{pH}$ values (4.0-8.0) for acidity-dependent experiments. Steady-state kinetics were measured using a Cary 60 UV-visible spectrometer at $340 \mathrm{~nm}$ $\left(\varepsilon_{340}=6220 \mathrm{~cm}^{-1} \mathrm{M}^{-1}\right)$. The temperature was regulated by a water bath at $30{ }^{\circ} \mathrm{C}$. Products were confirmed by gas chromatography (YL 6500GC system) using an Agilent HP-PLOT/Q stationery column $(30 \mathrm{~m} \times 0.535 \mathrm{~mm} \times 40.00 \mu \mathrm{m})$. All experiments were performed in the absence of substrates as a negative control, which did not exhibit SEA.

SEA were measured in $M$. sporium 5 and M. species $M$ using propylene. System I measured the activity by incubation with $\mathrm{MMOH}$ (1.0 mol equiv. from $M$. sporium 5$)$, MMOB (2.0 mol equiv. from Methylocystis sp. M), and MMOR (0.5 mol equiv. from M. sporium 5$)$. System II was incubated with $\mathrm{MMOH}$ (1.0 mol equiv. from M. sporium 5), MMOB (2.0 mol equiv. from M. sporium 5), and MMOR (0.5 mol equiv. from $M$. species $\mathrm{M}$ ).

\section{Conclusions}

To elucidate the catalytic mechanisms of sMMO, M. sporium 5 can be used for isolating intermediates. Oxidation rates were considerably different depending on the concentration and proportion of MMOB, and it was observed that more than 2 mol equiv. of MMOB may retard electron transfer by blocking MMOR. The methanotrophic bacterium M. sporium 5 has been investigated for more than four decades, but its physicochemical properties are not intensively understood compared with those of M. capsulatus Bath and M. trichosporium OB3b.

One of the interesting aspects of sMMO is its broad oxygenase ability, and this study confirmed that sMMO from $M$. sporium 5 can hydroxylate diverse substrates and epoxidize propylene. The enzyme activity of sMMO from M. sporium 5 was comparable to that of other sMMOs and showed 
relatively high enzyme activity for aromatic substrates. Furthermore, it was observed that substitution with MMOB and MMOR from another species, M. species M, retains its enzyme activity (Figure S10). The amino acid sequences of MMOB and MMOR between M. sporium 5 and M. species M showed $99 \%$ and $94 \%$ identity, respectively (Figure 1). MMOB and MMOR of M. species M were expressed and purified to measure SEA, and these results showed that substituting with MMOB and MMOR from other species restored activities (Figure S10). System I represents MMOB substitution from M. species M, and System II represents MMOR substitution from the same species. Enzymatic activities proved that MMOB and MMOR showed cross-reactivity between M. sporium 5 and M. species $\mathrm{M}$ because System I and II yielded SEA values of $527 \pm 8.3 \mathrm{mU} / \mathrm{mg}$ and $519 \pm 28.2 \mathrm{mU} / \mathrm{mg}$, respectively. The crossreactivity from $M$. capsulatus Bath and M. sporium 5 was tested, and results proved that enzymatic activities were unchanged [54]. These results prove that MMOB and MMOR retain their structural and functional roles with hydroxylase from other species. This fundamental study on purified enzymes of $M$. sporium 5 can provide another platform for further studying these complicated catalytic cycles.

Supplementary Materials: The following are available online at http:/ /www.mdpi.com/2073-4344/8/12/582/s1, Figure S1. Multiple sequence amino acid alignment of sMMO from Methylosinus sporium 5 (type II), Methylosinus trichosporium OB3b (type II), Methylocystis species M (type II), and Methylococcus capsulatus Bath (type X). (A) Alignment of amino acids from the $\alpha$-subunit of $\mathrm{MMOH}$ (GenBank accession number: ABD46892). Gray and red colors represent identical and different amino acids, respectively. Blue represents the identical residues among type II methanotrophs. (B) Alignment of amino acids from the $\beta$-subunit of MMOH (GenBank accession number: ABD46893). Gray and red colors represent identical and different amino acids, respectively. Blue represents the identical residues among type II methanotrophs. (C) Alignment of amino acids from the $\gamma$-subunit of MMOH (GenBank accession number: ABD46895). Gray and red colors represent identical and different amino acids, respectively. Blue represents the identical sequences among type II methanotrophs. Figure S2. Multiple amino acid alignment of MMOB (GenBank accession: ABD46894) from Methylosinus sporium 5 (type II), Methylosinus trichosporium OB3b (type II), Methylocystis species M (type II), and Methylococcus capsulatus Bath (type X). Figure S3. Multiple amino acid alignment of MMOR (GenBank accession: ABD46897) from Methylosinus sporium 5 (type II), Methylosinus trichosporium OB3b (type II), Methylocystis species M (type II), and Methylococcus capsulatus Bath (type X). Figure S4. Growth and pigmentation profile of sMMO from M. sporium 5 based on optical density at $600 \mathrm{~nm}$ $\left(\mathrm{OD}_{600}\right)$. (A) Cell growth at $\mathrm{OD}_{600}$ of 3.0 with one-time methane feeding (once/day). (B) Cell growth at $\mathrm{OD}_{600}$ of 8.2 with two-time methane supply (twice/day). Cultures A and B were proliferated for a week in media with the same iron concentration $(20.4 \mathrm{mg} / \mathrm{mL})$. Figure S5. Ferrozine assay of MMOH showed iron contents in MMOH $(3.8-4.1 \mathrm{Fe} / \mathrm{MMOH})$. The maximum wavelength was monitored at $562 \mathrm{~nm}$ from the iron-ferrozine complex. Heavy and light lines represent denatured $\mathrm{MMOH}$ and standard solutions, respectively. All experiments were performed in triplicate with $\mathrm{R}^{2}$ values $>0.999$. Figure $\mathrm{S} 6$. Constructed $\mathrm{pET} 30 \mathrm{a}-m m o B$ plasmids and UV-visible spectrum of MMOB after purification. (A) Lane 1 represents the control ladder, lane 2 represents the pET30a-mmoB construct, and lane 3 represents nucleotides after NdeI and HindIII double digestion. (B) UV-vis spectrum of MMOB after construction. Figure S7. Constructed $p E T 30 a-m m o C$ plasmid and ferrozine assays from MMOR (A) Lane 1 represents the control ladder, lane 2 represents the $p E T 30 a-m m o C$ construct, and lane 3 represents the $p E T 30 a-m m o C$ after NdeI and HindIII double digestion. (B) Ferrozine assay of MMOR for demonstrating the iron content in MMOR (2.03-2.14 Fe/MMOR). The maximum wavelength was monitored at $562 \mathrm{~nm}$ from the iron-ferrozine complex. Heavy and light lines represent iron solutions from denatured MMOR and standard solutions, respectively. All experiments were performed in triplicate with $R^{2}$ values $>0.998$. Figure S8. Specific enzyme activity based on the ratio of MMOR to MMOH in 2 mol equivalents of MMOB at pH 7.5. Figure S9. Constructed $p E T 30 a-m m o C-F A D$ plasmids. Lane 1 represents the control ladder, lane 2 represents the $p E T 30 a-m m o C$ construct, and lane 3 represents nucleotides after NdeI and HindIII double digestion. Figure S10. Measurement of crossreactivity in MMOB and MMOR. System I consists of MMOH (M. sporium 5), MMOB (M. species M), and MMOR (M. sporium 5). System II consists of MMOH (M. sporium 5), MMOB (M. sporium 5), and MMOR (M. species M). Specific enzymatic activities were measured at $30^{\circ} \mathrm{C}$ and $\mathrm{pH}$ 7.5. Table S1. Primers used in this study.

Author Contributions: D.-H.L. and S.J.L designed the experiments; Y.R.P, M.Y.S., and H.S.Y. performed the gene cloning, expression, and purification of enzymes and activity tests. Y.R.P. and S.J.L. characterize enzymes and activity tests; S.J.L wrote the manuscript.

Funding: This research was supported by the C1 Gas Refinery Program through the National Research Foundation of Korea (NRF-2015M3D3A1A01064876) and Basic Science Research Program through the National Research Foundation of Korea (NRF) funded by the Ministry of Education (2017R1A6A1A03015876).

Conflicts of Interest: The authors declare no conflicts of interest. 


\section{References}

1. Hanson, R.S.; Hanson, T.E. Methanotrophic bacteria. Microbiol. Rev. 1996, 60, 439-471. [PubMed]

2. Lawton, T.J.; Rosenzweig, A.C. Methane-oxidizing enzymes: An upstream problem in biological gas-to-liquids conversion. J. Am. Chem. Soc. 2016, 138, 9327-9340. [CrossRef] [PubMed]

3. Semrau, J.D.; DiSpirito, A.A.; Yoon, S. Methanotrophs and copper. FEMS. Microbiol. Rev. 2010, 34, $496-531$. [CrossRef] [PubMed]

4. Lieberman, R.L.; Rosenzweig, A.C. Biological methane oxidation: Regulation, biochemistry, and active site structure of particulate methane monooxygenase. Crit. Rev. Biochem. Mol. 2004, 39, 147-164. [CrossRef] [PubMed]

5. Sullivan, J.P.; Dickinson, D.; Chase, H.A. Methanotrophs, Methylosinus trichosporium OB3b, sMMO, and their application to bioremediation. Crit. Rev. Microbiol. 1998, 24, 335-373. [CrossRef] [PubMed]

6. Leahy, J.G.; Batchelor, P.J.; Morcomb, S.M. Evolution of the soluble diiron monooxygenases. FEMS Microbiol. Rev. 2003, 27, 449-479. [CrossRef]

7. Warmuzinski, K. Harnessing methane emissions from coal mining. Process Saf. Environ. 2008, 86, 315-320. [CrossRef]

8. Haynes, C.A.; Gonzalez, R. Rethinking biological activation of methane and conversion to liquid fuels. Nat. Chem. Biol. 2014, 10, 331-339. [CrossRef] [PubMed]

9. Sirajuddin, S.; Barupala, D.; Helling, S.; Marcus, K.; Stemmler, T.L.; Rosenzweig, A.C. Effects of zinc on particulate methane monooxygenase activity and structure. J. Biol. Chem. 2014, 289, 21782-21794. [CrossRef] [PubMed]

10. Sirajuddin, S.; Rosenzweig, A.C. Enzymatic oxidation of methane. Biochemistry 2015, 54, $2283-2294$. [CrossRef] [PubMed]

11. Wang, V.C.C.; Maji, S.; Chen, P.R.Y.; Lee, H.K.; Yu, S.S.F.; Chan, S.I. Alkane oxidation: Methane monooxygenases, related enzymes, and their biomimetics. Chem. Rev. 2017, 117, 8574-8621. [CrossRef] [PubMed]

12. Hakemian, A.S.; Rosenzweig, A.C. The biochemistry of methane oxidation. Annu. Rev. Biochem. 2007, 76, 223-241. [CrossRef] [PubMed]

13. Gassner, G.T.; Lippard, S.J. Component interactions in the soluble methane monooxygenase system from Methylococcus capsulatus (Bath). Biochemistry 1999, 38, 12768-12785. [CrossRef] [PubMed]

14. Merkx, M.; Kopp, D.A.; Sazinsky, M.H.; Blazyk, J.L.; Muller, J.; Lippard, S.J. Dioxygen activation and methane hydroxylation by soluble methane monooxygenase: A tale of two irons and three proteins. Angew. Chem. Int. Ed. 2001, 40, 2782-2807. [CrossRef]

15. Rosenzweig, A.C.; Nordlund, P.; Takahara, P.M.; Frederick, C.A.; Lippard, S.J. Geometry of the soluble methane monooxygenase catalytic diiron center in two oxidation states. Chem. Biol. 1995, 2, 409-418. [CrossRef]

16. Sazinsky, M.H.; Lippard, S.J. Correlating structure with function in bacterial multicomponent Monooxygenases and related diiron proteins. Acct. Chem. Res. 2006, 39, 558-566. [CrossRef] [PubMed]

17. Fox, B.G.; Froland, W.A.; Dege, J.E.; Lipscomb, J.D. Methane monooxygenase from Methylosinus trichosporium OB3b. J. Biol. Chem. 1989, 264, 10023-10033. [PubMed]

18. Hanson, R.S.; Wattenberg, E.V. Ecology of methylotrophic bacteria. Biotechnology 1991, 18, 325-348. [PubMed]

19. Banerjee, R.; Proshlyakov, Y.; Lipscomb, J.D.; Proshlyakov, D.A. Structure of the key species in the enzymatic oxidation of methane to methanol. Nature 2015, 518, 431-434. [CrossRef] [PubMed]

20. Elango, N.; Radhakrishnan, R.; Froland, W.A.; Wallar, B.J.; Earhart, C.A.; Lipscomb, J.D.; Ohlendorf, D.H. Crystal structure of the hydroxylase component of methane monooxygenase from Methylosinus trichosporium OB3b. Protein Sci. 1997, 6, 556-568. [CrossRef] [PubMed]

21. Rosenzweig, A.C.; Frederick, C.A.; Lippard, S.J.; Nordlund, P. Crystal structure of a bacterial nonheme iron hydroxylase that catalyzes the biological oxidation of methane. Nature 1993, 366, 537-543. [CrossRef] [PubMed]

22. Froland, W.A.; Andersson, K.K.; Lee, S.K.; Liu, Y.; Lipscomb, J.D. Methane monooxygenase component B and reductase alter the regioselectivity of the hydroxylase component-catalyzed reactions. A novel role for protein-protein interactions in an oxygenase mechanism. J. Biol. Chem. 1992, 267, 17588-17597. [PubMed] 
23. Lee, S.J.; McCormick, M.S.; Lippard, S.J.; Cho, U.S. Control of substrate access to the active site in methane monooxygenase. Nature 2013, 494, 380-384. [CrossRef] [PubMed]

24. Ali, H.; Scanlan, J.; Dumont, M.G.; Murrell, J.C. Duplication of the mmoX gene in Methylosinus sporium: Cloning, sequencing and mutational analysis. Microbiology 2006, 152, 2931-2942. [CrossRef] [PubMed]

25. Nakajima, T.; Uchiyama, H.; Yagi, O.; Nakahara, T. Purification and properties of a aoluble methane monooxygenase from Methylocystis sp. M. Biosci. Biotechnol. Biochem. 1992, 56, 736-740. [CrossRef] [PubMed]

26. Pilkington, S.J.; Dalton, H. Purification and characterization of the soluble methane monooxygenase from Methylosinus sporium 5 demonstrates the highly conserved nature of this enzyme in methanotrophs. FEMS Microbiol. Lett. 1991, 78, 103-108. [CrossRef]

27. Whittenbury, R.; Phillips, K.C.; Wilkinson, J.F. Enrichment, isolation and some properties of methane utilizing bacteria. J. Gen. Microbiol. 1970, 61, 205-218. [CrossRef] [PubMed]

28. Blazyk, J.L.; Gassner, G.T.; Lippard, S.J. Intermolecular electron transfer reactions in soluble methane monooxygenase: A role for hysteresis in protein function. J. Am. Chem. Soc. 2005, 127, 17364-17376. [CrossRef] [PubMed]

29. Blazyk, J.L.; Lippard, S.J. Expression and characterization of ferredoxin and flavin adenine dinucleotide binding domains of the reductase component of soluble methane monooxygenase from Methylococcus capsulatus (Bath). Biochemistry 2002, 41, 15780-15794. [CrossRef] [PubMed]

30. Liu, Y.; Nesheim, J.C.; Paulsen, K.E.; Stankovich, M.T.; Lipscomb, J.D. Roles of the methane monooxygenase reductase component in the regulation of catalysis. Biochemistry 1997, 36, 5223-5233. [CrossRef] [PubMed]

31. Tinberg, C.E.; Lippard, S.J. Revisiting the mechanism of dioxygen activation in soluble methane monooxygenase from $M$. capsulatus (Bath): Evidence for a multi-step, proton-dependent reaction pathway. Biochemistry 2009, 48, 12145-12158. [CrossRef] [PubMed]

32. Wang, W.X.; Iacob, R.E.; Luoh, R.P.; Engen, J.R.; Lippard, S.J. Electron transfer control in soluble methane monooxygenase. J. Am. Chem. Soc. 2014, 136, 9754-9762. [CrossRef] [PubMed]

33. Matsen, J.B.; Yang, S.; Stein, L.Y.; Beck, D.; Kalyuzhnaya, M.G. Global molecular analyses of methane metabolism in methanotrophic alphaproteobacterium, Methylosinus trichosporium OB3b. Part I: Transcriptomic study. Front. Microbiol. 2013, 4, 40. [CrossRef] [PubMed]

34. Semrau, J.D.; Jagadevan, S.; DiSpirito, A.A.; Khalifa, A.; Scanlan, J.; Bergman, B.H.; Freemeier, B.C.; Baral, B.S.; Bandow, N.L.; Vorobev, A.; et al. Methanobactin and MmoD work in concert to act as the 'copper-switch' in methanotrophs. Environ. Microbiol. 2013, 15, 3077-3086. [CrossRef] [PubMed]

35. Grosse, S.; Laramee, L.; Wendlandt, K.D.; McDonald, I.R.; Miguez, C.B.; Kleber, H.P. Purification and characterization of the soluble methane monooxygenase of the type II methanotrophic bacterium Methylocystis sp strain WI 14. Appl. Environ. Microbiol. 1999, 65, 3929-3935. [PubMed]

36. Merkx, M.; Lippard, S.J. Why OrfY? Characterization of MMOD, a long overlooked component of the soluble methane monooxygenase from Methylococcus capsulatus (Bath). J. Biol. Chem. 2002, 277, 5858-5865. [CrossRef] [PubMed]

37. Wang, W.X.; Liang, A.D.; Lippard, S.J. Coupling oxygen consumption with hydrocarbon oxidation in bacterial multicomponent monooxygenases. Acct. Chem. Res. 2015, 48, 2632-2639. [CrossRef] [PubMed]

38. Shaofeng, H.; Shuben, L.; Jiayin, X.; Jianzhong, N.; Chungu, X.; Haidong, T.; Wei, T. Purification and biochemical characterization of soluble methane monooxygenase hydroxylase from Methylosinus trichosporium IMV 3011. Biosci. Biotechnol. Biochem. 2007, 71, 122-129. [CrossRef] [PubMed]

39. Rosenzweig, A.C.; Brandstetter, H.; Whittington, D.A.; Nordlund, P.; Lippard, S.J.; Frederick, C.A. Crystal structures of the methane monooxygenase hydroxylase from Methylococcus capsulatus (Bath): Implications for substrate gating and component interactions. Proteins Struct. Funct. Genet. 1997, 29, 141-152. [CrossRef]

40. Atkin, C.L.; Thelande, L.; Reichard, P.; Lang, G. Iron and free-radical in ribonucleotide reductase-Exchange of iron and Mössbauer spectroscopy of protein B2 subunit of Escherichia coli Enzyme. J. Biol. Chem. 1973, 248, 7464-7472. [PubMed]

41. Brandstetter, H.; Whittington, D.A.; Lippard, S.J.; Frederick, C.A. Mutational and structural analyses of the regulatory protein B of soluble methane monooxygenase from Methylococcus capsulatus (Bath). Chem. Biol. 1999, 6, 441-449. [CrossRef]

42. Colby, J.; Stirling, D.I.; Dalton, H. The soluble methane mono-oxygenase of Methylococcus capsulatus (Bath): Its ability to oxygenate $n$-alkanes, ethers, and alicyclic, aromatic and heterocyclic compounds. Biochem. J. 1977, 165, 395-402. [CrossRef] [PubMed] 
43. Walters, K.J.; Gassner, G.T.; Lippard, S.J.; Wagner, G. Structure of the soluble methane monooxygenase regulatory protein B. Proc. Natl. Acad. Sci. USA 1999, 96, 7877-7882. [CrossRef] [PubMed]

44. Lund, J.; Dalton, H. Further Characterization of the FAD and $\mathrm{Fe}_{2} \mathrm{~S}_{2}$ redox centers of component C, the NADH-Acceptor reductase of the soluble methane monooxygenase of Methylococcus capsulatus (Bath). Eur. J. Biochem. 1985, 147, 291-296. [CrossRef] [PubMed]

45. Lund, J.; Woodland, M.P.; Dalton, H. Electron transfer reactions in the soluble methane monooxygenase of Methylococcus capsulatus (Bath). Eur. J. Biochem. 1985, 147, 297-305. [CrossRef] [PubMed]

46. Kopp, D.A.; Gassner, G.T.; Blazyk, J.L.; Lippard, S.J. Electron-transfer reactions of the reductase component of soluble methane monooxygenase from Methylococcus capsulatus (Bath). Biochemistry 2001, 40, 14932-14941. [CrossRef] [PubMed]

47. Fox, B.G.; Liu, Y.; Dege, J.E.; Lipscomb, J.D. Complex formation between the protein components of methane monooxygenase from Methylosinus trichosporium Ob3b. Identification of sites of component interaction. J. Biol. Chem. 1991, 266, 540-550. [PubMed]

48. Liu, K.E.; Lippard, S.J. Redox properties of the hydroxylase component of methane monooxygenase from Methylococcus capsulatus (Bath). Effects of protein B, reductase, and substrate. J. Biol. Chem. 1991, 266, 12836-12839. [PubMed]

49. Green, J.; Prior, S.D.; Dalton, H. Copper ions as inhibitors of protein C of soluble methane monooxygenase of Methylococcus capsulatus (Bath). Eur. J. Biochem. 1985, 153, 137-144. [CrossRef] [PubMed]

50. Lipscomb, J.D. Biochemistry of the soluble methane monooxygenase. Annu. Rev. Microbiol. 1994, 48, 371-399. [CrossRef] [PubMed]

51. Murrell, J.C.; Gilbert, B.; McDonald, I.R. Molecular biology and regulation of methane monooxygenase. Arch. Microbiol. 2000, 173, 325-332. [CrossRef] [PubMed]

52. Pulver, S.; Froland, W.A.; Fox, B.G.; Lipscomb, J.D.; Solomon, E.I. Spectroscopic studies of the coupled binuclear non-heme iron active site in the fully reduced hydroxylase component of methane monooxygenase: Comparison to deoxy and deoxy-azide hemerythrin. J. Am. Chem. Soc. 1994, 116, 4529-4529. [CrossRef]

53. McCormick, M.S.; Lippard, S.J. Analysis of substrate access to active sites in bacterial multicomponent monooxygenase hydroxylases: X-ray crystal structure of xenon-pressurized phenol hydroxylase from Pseudomonas sp. OX1. Biochemistry 2011, 50, 11058-11069. [CrossRef] [PubMed]

54. Stirling, D.I.; Dalton, H. Properties of the methane monooxygenase from extracts of Methylosinus trichosporium OB3b and evidence for its similarity to the enzyme from Methylococcus capsulatus (Bath). Eur. J. Biochem. 1979, 96, 205-212. [CrossRef] [PubMed]

(C) 2018 by the authors. Licensee MDPI, Basel, Switzerland. This article is an open access article distributed under the terms and conditions of the Creative Commons Attribution (CC BY) license (http:/ / creativecommons.org/licenses/by/4.0/). 